\title{
Türkiye'de Halka Açık Firmaların Sermaye Yapısı Belirleyicileri: İki Aşamalı Kesirli Regresyon Analizi Yaklaşımı \\ Rümeysa BİLGİN1 \\ Özet
}

Bu çalış̧mada, Türkiye'deki halka açık firmaların sermaye yapıları Íki-aşamalı Kesirli Regresyon Modeli yaklaşımı kullanarak incelenmiştir. Birinci aşamada kaldıraçsız bir firmanın ilk defa borçlanma kararını etkileyen faktörleri belirlemek için bir ikili-tepki modeli tahmin edilmiştir. Íkinci aşamada ise, hâlihazırda kaldıraçl firmaların sermaye yapısı belirleyicileri kesirli regresyon modeli kullanılarak incelenmiştir. Çalışma sonucunda sıfır kaldıraç olgusunun Borsa İstanbul'da geçerli olduğu görülmüştür. Dolayısı ile sermaye yapısı belirleyicilerini araştıran çalıșmalarda kaldıraçsız ve kaldıraçlı firmaların verilerini ayrı ayrı analiz eden iki aşamalı bir yaklaşım kullanılmalıdır. Kaldıraçsız bir firmanın ilk defa borç alma kararını etkileyen faktörler ile kaldıraçlı bir firmanın kaldıraç oranını etkileyen faktörlerin farklılaştı̆̆ı bulgusuna da ulaşılmıştır.

Anahtar kelimeler: Sermaye yapısı belirleyicileri, sıfır kaldıraç olgusu, iki-aşamalı kesirli regresyon modeli Jel Kodu: G3,G32

Determinants of Capital Structure for Publicly Traded Firms in Turkey: Two-Part Fractional Regression Analysis Approach

Abstract

This paper evaluates capital structure decisions of public firms in Turkey using a two-part fractional regression model approach. Firstly, a binary response model is estimated to analyse factors that affect an unlevered firm's decision to issue debt. Secondly, determinants of capital structure for leveraged firms are investigated by employing a fractional regression model. The results show that zero leverage phenomenon is valid in Borsa İstanbul. Therefore, data of leveraged and unleveraged firms should be modelled separately. Besides, factors affecting the initial borrowing decision of an unleveraged firm and factors affecting the leverage ratio of a leveraged firm are not same

Keywords: Determinants of capital structure, zero leverage phenomenon, two-part fractional regression model Jel Codes: G3,G32

\section{GíRiş}

$\mathrm{Bu}$ çalışmada ampirik sermaye yapısı literatüründe son dönemde ortaya çlkan yeni yaklaşımlar ışığında Türkiye'deki halka açık firmaların sermaye yapılarını etkileyen belirleyiciler araştırılmıştır. Türkiye verisi kullanılarak yapılmış daha önceki çalışmaların dikkate almadığı birkaç önemli husus bu çalışmada ele alınmıștır.

Ampirik sermaye yapısı literatürü sermaye yapısı belirleyicilerinin neler olduğu sorusuna cevap arar. Modigliani ve Miller (1958) çalışmasından beri geçen 60 yıllık süre zarfında bu literatür oldukça zenginleşmiştir. Ancak son on yılda, yapılan ampirik analizlerin geçerliliğini arttırmak için dikkat edilmesi gereken bazı hususlardan bahsedilmeye bașlanmıștır (Welch, 2011; Strabulaev ve Yang, 2013; Kieschnick ve Moussawi, 2018). Așağıda detaylı olarak açıklanacak bu hususların tümünü bir arada dikkate alan ilk Türkçe makale olması bakımından bu çalışmanın literatüre önemli bir katkı yapacağı düşünülmektedir.

İlk husus, bağımlı değișken olarak kullanılan kaldıraç oranının hesaplanmasında ortaya çıkmaktadır. Sermaye yapısı belirleyicilerini araştırmak için yapılan ampirik çalışmalarda kaldıraç oranı bağımsız değişken olarak kullanılmaktadır. Bu oran, literatürde birkaç farklı şekilde hesaplanmıștır. En sık kullanılan hesaplama yöntemlerinden biri ise finansal

ATIF ÖNERİSí (APA): Rümeysa, B. (2020). Türkiye'de Halka Açık Firmaların Sermaye Yapısı Belirleyicileri: İki Așamalı Kesirli Regresyon Analizi Yaklaşımı. İzmir Íktisat Dergisi, 35(3), 531-548. Doi: 10.24988/ije.202035307

1 Dr. Öğretim Üyesi, İstanbul Sabahattin Zaim Üniversitesi, İşletme ve Yönetim Bilimleri Fakültesi, Küçükçekmece/ISTANBUL, EMAIL: rumeysa.bilgin@izu.edu.tr ORCID:0000-0002-5919-0035 


\section{R. BILGIN}

borcun toplam varlıklara bölünmesi ile elde edilen kaldıraç orandır. Welch (2011)'in vurguladığı gibi, bu oran sadece borçluluğu düşük firmalar için değil ticari kredi kullanımı gibi borç dışı yükümlülükleri fazla olan firmalar için de düşük hesaplanmaktadır. Bu nedenle, şirketin gerçek borçluluğunu yansıtmamaktadır. Kaldıraç oranının, toplam finansal borcun toplam yatırıma oranı ya da toplam borcun toplam varlıklara oranı olarak hesaplanması daha doğru olacaktır. İleride detaylı şekilde açıklanacağı gibi bu çalışmada kaldıraç oranı, toplam finansal borcun toplam yatırıma (toplam finansal borç ve özsermaye toplamına) bölünmesi ile elde edilmiştir.

İkinci önemli husus ise, son dönemde dile getirilmeye başlanan sıfır kaldıraç olgusu (zero-leverage phenomenon)'dur. Bu olgu, bazı firmaların borç kullanmayı tercih etmemesi olarak açıklanabilir. Sıfır kaldıraç olgusu, ampirik olarak varlığı kanıtlanmış bir durum olmasına karşın modern sermaye yapısı teorileri bu olgunun nedenlerini açlklamakta yetersiz kalmaktadır (Strabulaev, 2007; Strabulaev ve Yang, 2013). Bu durum, kaldıraçsız bir firmanın borç kullanmaya başlama kararını etkileyen faktörler ile kaldıraçlı bir firmanın kaldıraç oranını etkileyen faktörlerin birbirinden farklı olma ihtimaline yol açmaktadır. Son birkaç yılda yapılan çalışmalarda sıfır kaldıraç olgusunun pek çok ülke için geçerli olduğu kanıtlanmıştır ( Bessler vd., 2013; Ramalho ve Silva 2009); Dang, 2013; El Ghoul vd., 2017). Ancak Borsa İstanbul'da sıfır kaldıraç olgusu daha önce araştırılmamıştır. $\mathrm{Bu}$ çalışma bu eksiği kapatmaktadır.

Bu çalışmanın Türkçe literatüre katkı sağlaması beklenen son husus ise kaldıraç değişkeninin dağılımı ile ilgilidir. Finansal borcun toplam yatırıma bölünmesi ile hesaplanan kaldıraç oranı 0 ile 1 aralığında değer alan kesirli bir değişkendir. Kesirli değișkenlerin koşullu beklentisinin açıklayıcı değişkenlerin doğrusal olmayan bir fonksiyonu olacağı ise açıktır (Papke ve Wooldridge, 1996).Dolayısıyla sermaye yapısı belirleyicileri ile ilgili çalışmalarda doğrusal modellerin kullanılması model spesifikasyonunun hatalı olmasina yol açacaktır. Ramalho ve Silva (2009) bu sorunun çözümü için Papke ve Wooldridge (1996) tarafından geliştirilen bir yarı-en çok olabilirlik (quasi-maximum likelihood-QML) tahmincisinin kullanılmasını önermişlerdir. Kesirli Regresyon Modeli (Fractional Regression Model-FRM) olarak isimlendirilen bu model, Papke ve Wooldridge (2008) tarafından panel veri için geliştirilen tahminci yardımı ile panel veri setlerinde de kullanılabilir.

Bu çalışmada, Borsa İstanbul'da işlem gören ve finans dışı sektörlerde faaliyet gösteren halka açık firmaların sermaye yapısı belirleyicileri Ramalho vd. (2011) tarafından geliștirilen 2aşamalı Kesirli Regresyon Modeli (2-Part Fractional Regression Model) yaklaşımı kullanılarak araştırılmıștır.

Çalışma sonucunda bazı firmaların sermaye yapılarına borç ile finansmanı dâhil etmedikleri bulgulanmıştır. Çalışma kapsamındaki firmaların \%31'i kaldıraçsızdır. Bu oran çalışma kapsamındaki yedi yıl içinde çok değișmemektedir. Bu durum, sıfır kaldıraç olgusunun Borsa İstanbul'da geçerli olduğunu göstermektedir. Dolayısı ile sermaye yapısı çalışmalarında kaldıraçsız ve kaldıraçlı firmaların verilerini ayrı ayrı analiz eden iki aşamalı bir modeller kullanılması gerekmektedir. Buna ek olarak, kaldıraçsız bir firmanın ilk defa borç alma kararını etkileyen faktörler ile kaldıraçlı bir firmanın ne kadar borç kullanacağını etkileyen faktörler farklılaşmaktadır. Karlılık ve piyasa değeri defter değeri oranı değişkenleri kaldıraçsız bir firmanın kaldıraç kullanmaya başlamasını etkiler. Ancak bu değişkenler kaldıraçlı bir firmanın kaldıraç oranını etkilemezler. Diğer taraftan varlık yapısı, firma büyüklüğü ve sektör kaldıraç ortalaması değişkenleri her iki durumda da etkili belirleyicilerdir.

Beş bölümden oluşan bu çalışmanın ilk bölümünde sermaye yapısı belirleyicileri ile ilgili literatüre kısaca değinilmiştir. İkinci bölümde, çalışmada kullanılan örneklem ve 
veri seti hakkında bilgi verilmiştir. Üçüncü bölümde ise uygulanan ekonometrik metot açıklanmıştır. Analiz sonuçları beşinci bölümde yorumlanmıştır.

\section{LITERATÜR TARAMASI}

Modigliani ve Miller (1958), belli varsayımlar altında firma değerinin sermaye yapısından bağımsız olduğunu göstermişlerdir. Değer ilişkisizliği yaklaşımı olarak adlandırılan bu görüş ancak yapılan bir dizi varsayım sağlandığında geçerlidir.

Modigliani ve Miller (1958;1963)'i takip eden süreçte elde edilen ilk ampirik bulgular bu varsayımların bir çoğunun gerçek hayatta sağlanmadığını göstermiștir (Harris ve Raviv, 1991). Dolayısı ile firma değeri sermaye yapısından etkilenmektedir. $\mathrm{Bu}$ durum firmaların sermaye yapılarını açıklamayı amaçlayan teorilerin doğuşuna yol açmıştır.

$\mathrm{Bu}$ yaklaşımların en eskisi olan Dengeleme Teorisi, dışsal finansman ihtiyacının bir kısmını ya da hepsini borç kullanarak karşılayan bir firmanın optimal kaldıraç oranını borcun sağladığı vergi avantajı ile yine borçluluğun artması ile oraya çıkan ödememe (iflas etme) riskinin dengelendiği noktada oluşacağını kabul eder (Modigliani ve Miller 1963). Buna karşın, Finansman Hiyerarşisi Hipotezi, kaldıraç oranının belirlenmesinde en önemli etken olarak asimetrik bilgi problemini ortaya koyar (Myers ve Majluf, 1984). Bu nedenle firmalar ancak dağıtılmamış karların yeni yatırımları finanse etmekte yetersiz kalması durumunda dişsal finansman sağlamak durumunda kalır. Bu noktada da borç ile finansmanı tercih ederler. Üçüncü ve son yaklaşım ise Serbest Nakit Akışı Hipotezi'dir (Jensen, 1986). Bu yaklaşım temsil probleminin önemini vurgular ve özellikle serbest nakit akışı oluşturma kapasitesi yüksek olan firmalarda, yöneticilerinin bu nakdi kendi kişisel çıkarları için harcamak yerine hissedarların faydasını gözetmesini garantilemek için borcun disipline edici bir mekanizma olarak kullanılmasını savunur.
Bu teorilerin ıșığında yapılan ampirik sermaye yapısı çalışmaları, yöneticilerin sermaye yapısı kararlarını etkiledikleri düşünülen bir dizi firmaya özgü faktörün var olduğunu göstermiştir. Sermaye yapısı belirleyicileri olarak isimlendirilen bu faktörlerin hangilerinin en büyük öneme sahip olduğu konusunda fikir ayrllıkları vardır. Harris ve Raviv (1991)'e göre kaldıraç oranı, varlık yapısı, borç dişı vergi kalkanı, büyüme kapasitesi ve firma büyüklügü faktörleri ile pozitif, kar volatilitesi ve karlılık faktörleri ile ise negatif ilişkilidir. Rajan ve Zingales (1995) ise piyasa değeri-defter değeri oranı, karlılık, varlık yapısı ve firma büyüklügü değişkenlerini en önemli firmaya özgü sermaye yapısı belirleyicileri olarak kabul etmişlerdir. Frank ve Goyal (2009) sektör kaldıraç ortalaması, varlık yapısı, firma büyüklüğü, karlılık, piyasa değeri-defter değeri oranı ve beklenen enflasyon oranı değişkenlerinin en temel sermaye yapısı belirleyicileri olduklarını ve sermaye yapısındaki değișkenliğin yaklaşık üçte birinin bu değişkenler ile açıklanabildiğini göstermişlerdir. Diğer taraftan, Graham ve Leary (2011), firmaların sermaye yapılarındaki değișkenliğin büyük kısmının sektör düzeyinde değil firma düzeyinde olduğunu, ancak literatürde kullanılan belirleyicilerin daha çok sektörler arası değişkenliği açıkladığını savunmuşlardır.

Firmaya özgü faktörlerin yanı sıra ülkeye özgü bazı faktörlerin de firmaların sermaye yapıları üzerinde etkili olduğunu gösteren ampirik çalışmalar vardır (Rajan ve Zingales, 1995; Antoniou vd, 2008; Kayo ve Kimura, 2011; Fan vd, 2012; Venanzi vd. 2014). Bu çalışmalar sonucunda ülkeye özgü faktörlerin firma kaldıraç oranları üzerindeki doğrudan etkilerinin yanı sıra firmaya özgü belirleyiciler üzerinde dolaylı etkilerinin de olduğu görülmüştür (De jong vd, 2008). Bu etkiler firmaya özgü sermaye yapısı belirleyicileri ile kaldıraç oranı arasındaki korelasyonun büyüklüğünün yanı sıra ilişkinin yönünü de etkileyebilmektedir. Dolayısı ile çoğunlukla ABD ve diğer gelișmiş ülkelerdeki firmalar analiz edilerek belirlenmiş yukarıdaki firmaya 
özgü değișkenler ile kaldıraç oranı ilişkilerinin diğer ülkelerde geçerli olmayabileceği düşünülebilir. $\mathrm{Bu}$ durum, ülke bazlı ampirik çalışmaları gerekli kılmaktadır.

Türkiye özelinde yapılmış sermaye yapısı çalışmaları incelendiğinde ise, elde edilen bulguların genellikle ABD verisi kullanılarak yapılmış çalışmaların bulgularıyla benzer olduğu görülmektedir (Burucu ve Öndeș, 2016; Aydın ve Çavdar, 2018; Kısakürek ve Aydın, 2013; Terim ve Kayalı, 2009; Toraman ve Okuyan, 2009; Demirhan, 2009; Köksal ve Orman, 2015). Ancak Türkçe literatürde yer alan çalışmaların büyük çoğunluğunda ekonometrik uygulama konusunda ciddi eksiklikler vardır. $\mathrm{Bu}$ durum yapılan çalışmalardan elde edilen sonuçların geçerliliği konusunda soru işaretlerine yol açmaktadır. Çoğu çalışmada, bağımsız değişken olarak Welch (2011) tarafından hatalı olduğu kanitlanan toplam uzun vadeli borcun toplam varlıklara bölünmesi ile elde edilen kaldıraç oranı kullanılmıștır. Panel veri kullanan çalışmalarda karşılaşılan diğer bir sorun ise yatay kesit bağımlılık probleminin göz ardı edilmesidir. Bazı çalışmalarda yatay kesit bağımlılık test edilmeden birinci nesil birim kök testleri kullanılmıştır. Yatay kesit bağımlılığın var olduğu durumda birinci nesil birim kök testleri geçersizdir (Baltagi, 2008). Dolayısı ile bu testlerin sonuçlarına göre değişkenlerin düzeylerinde modele dâhil edildiği analizlerin tekrarlanması sonuçların geçerliliği açısından tavsiye edilebilir.

Diğer taraftan, özellikle firma düzeyinde farklı yıllara ait verileri içeren panel veri setlerinin ampirik sermaye yapısı çalışmalarında kullanılmaya başlanması sermaye yapısı literatürüne yeni bir boyut kazandırmıştır. Dengeleme Teorisi'nin savunduğu optimal sermaye yapısı yaklaşımına göre her firma için borcun sağladığı vergi avantajı ile yol açtığı iflas maliyetlerinin dengelendiği noktada ortaya çıkan bir hedef sermaye yapısı vardır. Firmalar, bu hedef sermaye yapısına ulaşabilmek için kaldıraç oranlarını devamlı olarak değiştirirler.
Dolayısı ile $t+1$ dönemindeki kaldıraç oranının en iyi belirleyicisi $t$ dönemindeki kaldıraç oranidır (Parson ve Titman, 2009). Bu durum, panel veriler için oluşturulan sermaye yapısı modellerinin dinamik olması görüşünü ortaya çlkarmıştır. Ancak dinamik modellerde içsellik problemi ortaya çıktığı için Arellano ve Bond (1991) ile Blundell ve Bond (1998) tarafından geliştirilen System GMM tahmincisi kullanılmaya başlanmıştır (Ozkan, 2001; Antoniou vd., 2008; Baum ve diğ., 2017; Gonzalez ve Gonzalez, 2011; Huang ve Ritter, 2009). Bu tahminci bağımsız değişkenlerdeki içsellik sorununun çözümü için araç değişken kullanımını gerekli kılmaktadır. Araç değișkenlerin modeldeki bağımsız değișkenler ile korelasyonlarının düşük olması, diğer bir ifade ile araç değişkenlerin geçersiz olması durumunda analiz sonuçları da geçersiz olmaktadır. Diğer bir yaklaşım ise sermaye yapısı belirleyicilerinin hiyearaşik yapısını dikkate alan çalışmalarda kullanılan hiyerarşik Lineer model yaklaşımıdır (Kayo ve Kimura, 2011; Bilgin, 2018).

\section{VERİ SETİ}

Kullanılan veri seti 2011-20017 tarihleri arasında Borsa İstanbul'da işlem gören firmalar arasından Compustat IQ veri tabanında firma düzeyinde finansal verileri yayınlanan ve finans sektörü dişında faaliyet gösteren 337 firma'ya ait yıllık veriler kullanılarak hazırlanmaya başlanmıştır. İlk aşamada çalışma periyodunun en az bir yılında negatif özsermayesi olan 21 firma çalışma kapsamının dışında bırakılmıştır. İkinci aşamada, çalışma periyodunun kapsadığı yılların herhangi birinde Compustat veri tabanından alınan bilanço verilerinde eksiklik bulunan firmalar da çıkarıldığında firma sayısı 261'e düşmüștür. Bu 261 firmanın 2011-2017 yılları arası firma düzeyinde yıllık verilerini içeren bir panel veri seti oluşturulmuştur. Bu panel veri setine eklenen ülke düzeyindeki veriler ise Dünya bankası Dünya Gelişmişlik Göstergeleri arasından derlenmiştir. 

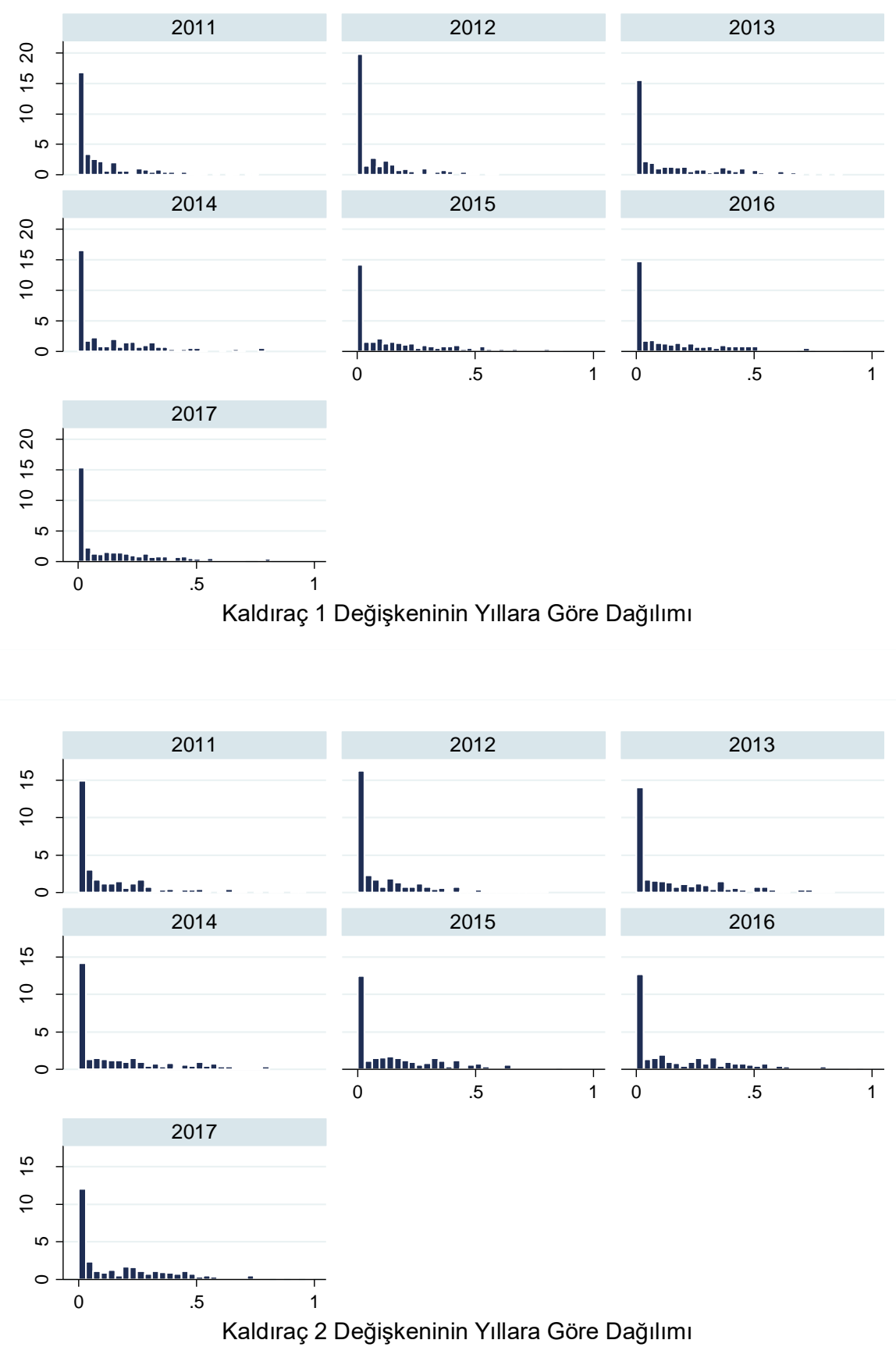

Şekil 1: Bağımlı Değişkenlerin Yıllara Göre Dağılımları

Bu çalışmada kaldıraç oranı bağımsız değişken olarak kullanılmıştır. Welch (2011)'in açıkladığı gibi, firmaların finansal (faiz ödenen) yükümlülüklerinin yanı sıra ticari krediler, ödenecek giderler gibi faiz ödenmeyen yükümlülükleri de vardır. Dolayısı ile firmanın finansal yükümlülüklerinin toplam varlıklarına bölünmesi ile elde edilen kaldıraç oranı hesaplaması firmanın sermaye yapısı tercihini doğru yansıtmayacaktır. Bu oranın paydasında özsermaye ve finansal borcun yanı sıra finansal olmayan yükümlülükler de yer alacaktır. $\mathrm{Bu}$ nedenle, hesaplanacak kaldıraç oranı sadece özsermaye finansmanını tercih eden firmalar için değil finansal olmayan yükümlülükleri fazla olan firmalar için de düşük olacaktır. $\mathrm{Bu}$ nedenle, çalışmada kullanılan kaldıraç oranı iki farklı şekilde hesaplanmıştır. Özsermayenin 


\section{R. BILGIN}

piyasa değeri ile hesap edilen Kaldıraç 1 değişkeni finansal borcun toplam yatırıma bölünmesi ile hesaplanmıștır. Burada finansal borç, uzun ve kısa vadeli faiz ödenen borçların toplamını ifade etmektedir. Toplam yatırım ise finansal borç ile özsermayenin piyasa değerlerinin toplanması ile elde edilir. Özsermayenin piyasa değeri dolaşımdaki hisse senedi sayısı ile hisse senedinin yılsonu kapanış fiyatının çarpılması ile hesap edilmiştir. Compustat veri tabanı çalışmada kullanılan 261 şirketin bazı yıllarına ait hisse senedi verisini yayınlamadığı için bu değişkende kayıp gözlemler oluşmuştur. İkinci hesaplama ile elde edilen Kaldıraç 2 değişkeni için ise finansal borç toplam yatırıma bölünürken özsermayenin piyasa değeri yerine defter değeri kullanılmıștır. Bu iki kaldıraç oranına ait tanımlayıcı istatistikler Tablo 1'de verilmiștir.

Tablo 1: Bağımlı değișken kaldıraç oranının tanımlayıcı istatistikleri

\begin{tabular}{|c|c|c|c|c|c|c|c|}
\hline Yll & İstatistikler & Kaldıraç 1 & Kaldıraç 2 & Yll & İstatistikler & Kaldıraç 1 & Kaldıraç 2 \\
\hline \multirow{8}{*}{2011} & Ortalama & 0.1160 & 0.1330 & \multirow{8}{*}{2015} & Ortalama & 0.1770 & 0.1866 \\
\hline & Medyan & 0.0390 & 0.0429 & & Medyan & 0.0944 & 0.1074 \\
\hline & St. Sapma & 0.1658 & 0.1948 & & St. Sapma & 0.2133 & 0.2169 \\
\hline & Çarpıklık & 1.7401 & 1.9047 & & Çarpıklık & 1.2495 & 1.1312 \\
\hline & Basıklık & 5.4859 & 6.4405 & & Basıklık & 3.7692 & 3.4216 \\
\hline & Minimum & 0.0000 & 0.0000 & & Minimum & 0.0000 & 0.0000 \\
\hline & Maksimum & 0.7402 & 0.9433 & & Maksimum & 0.8637 & 0.8946 \\
\hline & $\mathrm{N}$ & 214 & 261 & & $\mathrm{~N}$ & 258 & 261 \\
\hline \multirow{8}{*}{2012} & Ortalama & 0.0931 & 0.1208 & \multirow{8}{*}{2016} & Ortalama & 0.1777 & 0.1948 \\
\hline & Medyan & 0.0204 & 0.0279 & & Medyan & 0.0815 & 0.0985 \\
\hline & St. Sapma & 0.1379 & 0.1764 & & St. Sapma & 0.2174 & 0.2287 \\
\hline & Çarpıklık & 1.7426 & 1.7145 & & Çarpıklık & 1.2278 & 1.1334 \\
\hline & Basıklık & 5.3457 & 5.3710 & & Basıklık & 3.6691 & 3.5094 \\
\hline & Minimum & 0.0000 & 0.0000 & & Minimum & 0.0000 & 0.0000 \\
\hline & Maksimum & 0.5780 & 0.7913 & & Maksimum & 0.8687 & 0.9947 \\
\hline & $\mathrm{N}$ & 240 & 261 & & $\mathrm{~N}$ & 258 & 261 \\
\hline \multirow{8}{*}{2013} & Ortalama & 0.1621 & 0.1648 & \multirow{8}{*}{2017} & Ortalama & 0.1573 & 0.1941 \\
\hline & Medyan & 0.0660 & 0.0680 & & Medyan & 0.0686 & 0.1077 \\
\hline & St. Sapma & 0.2035 & 0.2086 & & St. Sapma & 0.1949 & 0.2221 \\
\hline & Çarpıklık & 1.2402 & 1.2833 & & Çarpıklık & 1.3067 & 1.1225 \\
\hline & Basıklık & 3.6354 & 3.7623 & & Basıklık & 3.9999 & 3.5935 \\
\hline & Minimum & 0.0000 & 0.0000 & & Minimum & 0.0000 & 0.0000 \\
\hline & Maksimum & 0.8712 & 0.8345 & & Maksimum & 0.8142 & 0.9873 \\
\hline & $\mathrm{N}$ & 247 & 261 & & $\mathrm{~N}$ & 255 & 261 \\
\hline \multirow{8}{*}{2014} & Ortalama & 0.1417 & 0.1708 & \multirow{8}{*}{ 2011-2017 } & Ortalama & 0.1476 & 0.1664 \\
\hline & Medyan & 0.0593 & 0.0779 & & Medyan & 0.0585 & 0.0686 \\
\hline & St. Sapma & 0.1852 & 0.2131 & & St. Sapma & 0.1930 & 0.2107 \\
\hline & Çarpıklık & 1.4900 & 1.1650 & & Çarpıklık & 1.4443 & 1.3285 \\
\hline & Basıklık & 4.7457 & 3.2563 & & Basıklık & 4.4296 & 4.0186 \\
\hline & Minimum & 0.0000 & 0.0000 & & Minimum & 0.0000 & 0.0000 \\
\hline & Maksimum & 0.7794 & 0.7959 & & Maksimum & 0.8712 & 0.9947 \\
\hline & $\mathrm{N}$ & 255 & 261 & & $\mathrm{~N}$ & 1727 & 1827 \\
\hline
\end{tabular}


Tablo 1 incelendiğinde ilk dikkati çeken husus hemen tüm yıllar için ve toplamda Kaldıraç 1 ve Kaldıraç 2 değişkenlerinin ortalama değerlerinin birbirlerinden çok farklı olmamasıdır. Medyan değerleri de kendi içerisinde benzer sayılabilir. Ancak ortalama ve medyan değerleri arasındaki hemen her yıl için ve toplamda gözlenen büyük farklılık bu değişkenlerin yıllık dağılımlarının normal olmadığını göstermektedir. Kaldıraç 1 ve 2 değişkenlerinin yıllara göre dağılımları Şekil 1'deki grafiklerde verilmiştir. Bu grafiklerde de görüldüğü gibi Kaldıraç 1 ve 2 değişkenlerinde çok sayıda firmanın finansal borç değerlerinin sıfır olmasından kaynaklı bir taban etkisi görülmektedir. $\mathrm{Bu}$ etki yüzünden dağılımlar sağa çarpıktır. Bu bulgu, sermaye yapısı belirleyicilerini araştıran çalışmalarda Strabulaev (2007) ve Starbulaev ve Yang (2013) tarafından dikkat çekilen sıfır kaldıraçlı firmaların varlığının dikkate alınması gerektiğini ortaya koymaktadır.

Çalışma kapsamında yer alan firmalar MSCI ve Standard \& Poor's tarafından geliştirilen Global Industry Classification Standart (GICS)'a göre 10 farklı sektörde yer almaktadır. Bu sektörler ve her sektördeki firma ve gözlem sayıları Tablo 2'de verilmiştir. Toplam verideki gözlem oranı \%10'un üstünde olan hammadde imalatı, üretim, talebin fiyat esnekliği olan ürünler ve talebin fiyat esnekliği olmayan ürünler sektörlerine ait kukla değişkenler modele eklenmiştir. Bunun yanında, firmaların kaldıraç oranları üzerindeki sektör kaynaklı etkiyi ortaya çıkarmak amacı ile örneklem periyodundaki her yıl için sektör kaldıraç ortalamalarının hesap edilmesi ile olușturulan bir sektör ortalama kaldıraç değişkeni de modele eklenmiştir.

Tablo 2: Sektör frekans tablosu

\begin{tabular}{llcccc}
\hline $\begin{array}{l}\text { GICS Sektör } \\
\text { Kodu }\end{array}$ & Sektör & $\begin{array}{c}\text { Firma } \\
\text { Sayısı }\end{array}$ & $\begin{array}{c}\text { Gözlem } \\
\text { Sayısı }\end{array}$ & Oran & $\begin{array}{c}\text { Kümülatif } \\
\text { Oran }\end{array}$ \\
\hline \hline 10 & Enerji & 5 & 35 & 1.9 & 1.9 \\
\hline 15 & Hammadde İmalatı & 61 & 427 & 23.19 & 25.1 \\
\hline 20 & Üretim & 55 & 385 & 20.91 & 46.01 \\
\hline 25 & Talebin Fiyat Esnekliği Olan Ürünler & 68 & 4476 & 26.62 & 72.62 \\
\hline 30 & Talebin Fiyat Esnekliği Olmayan Ürünler & 35 & 245 & 13.31 & 85.93 \\
\hline 35 & Sağlık & 5 & 35 & 1.9 & 87.83 \\
\hline 40 & Holding & 13 & 91 & 4.94 & 92.78 \\
\hline 45 & Bilgi Teknolojileri & 12 & 84 & 4.56 & 97.34 \\
\hline 50 & Telekomünikasyon & 2 & 14 & 0.76 & 98.1 \\
\hline 55 & Elektrik Gaz ve Su & 5 & 35 & 1.9 & 100 \\
\hline Toplam & & 261 & 1827 & 100 & \\
\hline
\end{tabular}

Çalışma kapsamında, literatürde genel kabul görmüş firma düzeyi sermaye yapısı belirleyicileri olan karlılık, firma büyüklügüü, varlık yapısı, borç dışı vergi kalkanı ve defter değeri-piyasa değeri oranı değişkenleri bağımsız değişken olarak kullanılmıştır. Bunlara ek olarak kullanılan bağımlı değișkene göre hesaplanan sektörlerin yıllık kaldıraç ortalamaları da modele eklenmiştir. Makro düzeydeki sermaye yapısı belirleyicilerini ortaya çıkarmak amacı ile ise literatürde sıklıkla kullanılan enflasyon ve GSYIH büyümesi tercih edilmiştir. Bu değişkenlerin açıklamaları, hesaplanmasında kullanılan formüller, alındıkları veri setleri $\mathrm{EK}$ 1'de verilmiştir.

\section{METOT}

Sermaye yapısı belirleyicilerini araştırmak için yapılan ampirik çalışmalarda kaldıraç oranı bağımsız değișken olarak kullanılmaktadır. Kaldıraç oranı literatürde birkaç farklı şekilde hesaplanmıştır. Welch (2011) ise şirketin 
borçluluk oranını mümkün olduğunca doğru hesaplanabilmesi için kaldıraç oranının doğru formüle edilmesi gerektiğini belirtmiş ve literatürdeki yanlış uygulamalara dikkat çekmiştir. Finansal borcun toplam varlıklara bölünmesi ile elde edilen kaldıraç oranın sadece borçluluğu düşük firmalar için değil ticari kredi kullanımı yüksek olan firmalar için de düşük çıkacağını belirtmiştir. Bunun yerine, şirketin gerçek borçluluk değerinin finansal borcun toplam yatırıma oranı ya da toplam borcun toplam varlıklara oranı olarak hesaplanabileceğini göstermiştir. Her iki oran da sinırlı (bounded) kesirli değişkenler elde etmemize neden olmaktadır. Bunun yansıra, kaldıraç bu iki orandan biri ile hesaplandığı takdirde borçsuz (sıfır kaldıraçlı) firmaların varlığı (Strabulaev 2008; Strabulaev ve Yang 2013) da dikkate alınmalıdır. Sonuç olarak ampirik çalışmalarda bağımsız değişken olarak kullanılan kaldıraç oranı değișkeni $y ; 0 \leq y \leq 1$ ve $\mathrm{P}(\mathrm{y}=0)>0$ ya da $\mathrm{P}(\mathrm{y}=1)>0$ olarak tanımlayabileceğimiz bir kesirli değișkendir (Wooldridge, 2011). Kesirli değişkenler belirli bir aralıkta değer aldıkları ve bu aralığın uç değerleri de gözlemlenebileceği için dağılımın normal olmayacağı açıktır. Bu nedenle doğrusal bir model bu tür değişkenler için uygun olmamaktadır (Papke ve Wooldridge, 1996). Son yıllarda, kaldıraç oranını bağımlı değişken olarak kullandıkları çalışmalarda bu problemin çözümü üzerine yoğunlaşan çalışmalar yapılmaya başlanmıştır (Ramalho ve Silva, 2009; Ramalho vd., 2011; Kieschnick ve Moussawi, 2018).

Sınırlı kesirli bir değişken olan kaldıraç oranının açıklayıcı değişkenler matrisine bağlı koşullu beklenen değeri doğrusal bir model kullanılarak açıklanamaz. $\mathrm{Bu}$ değişkenin beklenen değeri, eşitlik(1)'de gösterildiği gibi modellenebilir.

$E(y \mid X)=G(X \beta)$

burada $\boldsymbol{y}$ kaldıraç oranı vektörü, $\boldsymbol{X}$ sabit terim de dahil olmak üzere tüm açıklayıcı değişkenler matrisi, $\boldsymbol{\beta}$ katsayılar vektörüdür. Beklenen değerin istenen sınırlar içinde olabilmesi için $\boldsymbol{G}($.$) kümülatif dağılım fonksiyonu \mathbf{0}<\boldsymbol{G}()<$. 1 koşulunu sağlamalıdır. $\mathrm{Bu}$ koşulun sağlanması için eşitlik(1) doğrusal olmayan EKK metodu ile tahmin edilebilir. Daha basit bir alternatif olarak ise bağımlı değişken için uygun bir fonksiyonel form varsayımı yapilarak, Papke ve Wooldridge (1996) tarafından önerilen bir yarı maksimum en çok olabilirlik (quasi-maximum likelihood-QML) metodu kullanılabilir. Bu yöntemde $\boldsymbol{G}($.$) için$ doğru fonksiyonel form tahmini oldukça önemlidir. Ramalho vd. (2011) lojistik, normal, cauchy, loglog ve tamamlayıcı loglog kümülatif dağılım fonksiyonlarını karşılaştırmış ve bu beş dağılımın da kullanılabileceği sonucuna ulaşmışlardır. Papke ve Wooldridge (1996) lojistik fonksiyonu önermişlerdir ve Eşitlik(2)'de verilen Bernoulli log olabilirlik fonksiyonunu kullanmıșlardır.

\section{$L L(\beta)=y \log [G(X \beta)]+(1-y) \log [1-$ $G(X \beta)]$}

$\boldsymbol{G}($.$) fonksiyonu doğru belirlendiği takdirde$ kullanılan QML tahmincisinin katsayı tahminleri tutarlı olacaktır (Gourieroux vd. 1984).

Diğer taraftan Starbulaev (2007) ve Strabulaev ve Yang (2013) kendilerinden önceki ampirik sermaye yapısı çalışmalarında göz ardı edilen bir fenomene dikkat çekmişlerdir. Şirketlerin kaldıraç oranları hesaplandığında azımsanamayacak sayıda firmanın kaldıraç oranlarının sıfır olduğunu bulgulamışlardır. Bu nedenle, daha önce hiç borç almamış bir firmanın borç kullanıp kullanmama kararı ile hâlihazırda borçlu bir firmanın ne kadar borç kullanacağını etkileyen faktörlerin ve/veya etkileme düzeylerinin birbirinden farklı olabileceği düşünülebilir. Bu durumda, kaldıraç değişkeninin beklenen değeri hesap edilirken kaldıraçlı ve kaldıraçsız firmalara ait gözlemlerin bir arada aynı modelde analiz edilmesi doğru sonuç vermeyecektir. $\mathrm{Bu}$ nedenle, Ramalho ve Silva (2009) ve Ramalho vd. (2011) ampirik sermaye yapısı çalışmalarında iki aşamalı bir model kullanmayı önermiştir. 2-aşamalı Kesirli Regresyon Modeli (2-Part Fractional Regression Model) olarak isimlendirilen bu yaklaşımda iki farklı model kullanılmaktadır. İlk model olan İkili Tepki Modeli (Binary 
Response Model) aşağıdaki şekilde tanımlanabilir

$$
y^{*}=\left\{\begin{array}{c}
0 \text { for } y=0 \\
1 \text { for } y \in(0,1]
\end{array}\right.
$$

$P\left(y^{*}=1 \mid X\right)=P(y \in(0,1] \mid X)=F(X \theta)$

burada $\boldsymbol{y}^{*}$ kaldıraçlı firma için 1 , kaldıraçsız firma için ise 0 değerini alan ikili (binary) kaldıraç oranı değişkenidir. $\theta$ katsayı vektörü, $\mathrm{F}($.$) ise lojistik, normal, cauchy, loglog ve$ tamamlayıcı loglog olabilecek bağlantı (link) fonksiyonudur. Son olarak X, sabit terimi de içeren bir tüm bağımsız değişkenler matrisidir. $\mathrm{Bu}$ model QML tahmincisi ile tahmin edilir (Ramalho ve Silva, 2009). Bu şekilde firmaların borç kullanıp kullanmama kararlarını etkileyen faktörleri incelenebilir.

İkinci aşamada tahmin edilen Kesirli Regresyon Modeli (Fractional Regression Model) ise aşağıdaki şekilde ifade edilebilir,

$E(y \mid X, y \in(0,1])=G(X \gamma)$

burada y sadece borç kullanan firmalar için hesap edilen kaldıraç oranıdır. Bu oran 0 ile 1 arasında herhangi bir değer alabilir. $\gamma$ katsayı vektörü, G(.) ise lojistik, normal, cauchy, loglog ve tamamlayıcı loglog olabilecek bağlantı (link) fonksiyonudur. Ancak Papke ve Wooldridge (2008) bu fonksiyonu probit olarak kabul etmenin uygun olacağını belirtmişlerdir. Model QML tahmincisi ile tahmin edilir (Ramalho ve Silva, 2009). Böylece, hâlihazırda kaldıraç kullanan firmaların borç kullanımını etkileyen faktörler tespit edilmiş olur.

Kesirli regresyon modelini panel veriye uygulamak da nispeten basittir. $\boldsymbol{i}$ yatay kesit için $\boldsymbol{t}$ zamana ait gözlemlerden oluşan bir bağımlı değișken olan $y_{i t}, \quad \mathbf{0} \geq \boldsymbol{y}_{i t} \geq \mathbf{1}$ aralığında değer alıyor olsun. $\mathrm{Bu}$ bağımlı değişkeni açıklamak için kullanılan bağımsız değişkenler matrisi $\boldsymbol{x}_{\boldsymbol{i}}$ ve $\boldsymbol{c}_{\boldsymbol{i}}$ ise yatay kesit birime ait gözlemlenemeyen etki iken,

$E\left(y_{i t} \mid x_{i t}, c_{i}\right)=F\left(x_{i t} \beta+c_{i}\right)$

olarak yazılsın. Papke ve Wooldridge (2008)'i takip ederek, bağlantı (link) fonksiyonu $\boldsymbol{F}($.$) 'in$ standart normal kümülatif dağılım fonksiyonu olduğu varsayılmıștır. İlk aşamada $\boldsymbol{x}_{\boldsymbol{i}}{ }^{\prime}$ 'nin $\boldsymbol{c}_{\boldsymbol{i}}$ 'ye koşullu olarak kesin dışsal olduğu kabul edilmiştir. Ayrıca, bağımlı değişkenin kesirli olması nedeni ile $\operatorname{Var}\left(\boldsymbol{y}_{i t} \mid \boldsymbol{x}_{\boldsymbol{i t}}\right)^{\prime}$ nin heteroskedastik olduğu kesindir (Papke ve Wooldridge, 2008). Bu modeli tahmin etmek için Papke ve Wooldridge (2008) "havuzlanmış kesirli probit tahmincisi (pooled fractional probit estimator-PFP) adını verdikleri bir tahminci geliştirmişlerdir.

Sonuç olarak, Papke ve Wooldridge (1996, 2008) tarafından geliștirilen kesirli regresyon analizi, Ramalho ve Silva (2009) ve Ramalho vd. (2011) tarafından kullanılan 2-aşamalı Kesirli Regresyon Modeli'nin ikinci aşaması olarak bu çalışmada da kullanılmıştır. İlk aşamada ise panel logit regresyon analizi kullanılarak kaldıraçsız firmaların borç kullanma kararlarını etkileyen faktörler incelenmiştir.

\section{ANALIZ}

$\mathrm{Bu}$ çalışmada kullanılan veri seti hem yatay kesit hem de panel veri analiz yöntemleri kullanılarak analiz edilmiştir. Yatay kesit analizinde çalışma periyodundaki her bir yıla özgü veri setleri oluşturularak analiz yedi yıl için tekrarlanmış, panel veri analizinde ise örneklemdeki tüm firmaların tüm yıllar için verileri bir arada analiz edilmiștir. Böyle bir yaklaşımın tercih edilmesinin nedeni her yatay kesit analizde kesirli bağımsız değişken ve link fonksiyonları için belirlenen dağılımların geçerliliğinin test edilebilmesidir. Böylece elde edilen tahminlerin geçerliliği için oldukça önemli olan dağılım ile ilgili varsayımların geçerliliği kontrol edilmek istenmiştir.

\subsection{Yatay kesit analizi sonuçları}

İlk aşamada, Ramalho ve Silva (2009) ve Ramalho vd. (2011) tarafından geliştirilen 2aşamalı Kesirli Regresyon Modeli kullanılarak kaldıraçsız ve kaldıraçlı firmaların borç kullanma kararlarını etkileyen faktörler örneklem periyodunun her bir yılı için ayrı ayrı incelenmiştir. Yatay kesit analizlerde bağımlı değişken olarak Kaldıraç 2 kullanılmıştır. Sonuçlar Tablo 3a ve Tablo 3b'de verilmiştir. 


\section{R. BILGIN}

Tablo 3a:İki-aşamalı yatay kesit kesirli regresyon modeli ikili tepki bileşeni

Bu tabloda yatay kesit veri ile tahmin edilen 2-aşamalı kesirli regresyon modelinin sonuçları verilmiştir. Bağımlı değişken olarak Kaldıraç 2 oranı kullanılmıştır. Varyans-kovaryans matrisinin hesaplanmasında robust tahmin ediciler kullanılmıştır. Robust standart hatalar parantez içinde verilmiştir. “*”, “**” ve “***” sırasıyla\% 10,\% 5 ve\% 1 düzeyinde anlamlılığı göstermektedir. Değişken açıklamaları ise Ek 1'e verilmiştir.

\begin{tabular}{|c|c|c|c|c|c|c|c|}
\hline & 2011 & 2012 & 2013 & 2014 & 2015 & 2016 & 2017 \\
\hline Karlılık & $\begin{array}{l}-0.816 \\
(1.872)\end{array}$ & $\begin{array}{l}3.873^{* *} \\
(1.865)\end{array}$ & $\begin{array}{l}-2.923 \\
(2.384)\end{array}$ & $\begin{array}{l}-3.103 \\
(2.117)\end{array}$ & $\begin{array}{l}-2.528 \\
(1.707)\end{array}$ & $\begin{array}{l}-2.586^{*} \\
(1.339)\end{array}$ & $\begin{array}{l}-2.858 \\
(2.204)\end{array}$ \\
\hline $\begin{array}{l}\text { Varlık } \\
\text { Yapısı }\end{array}$ & $\begin{array}{l}3.765^{* * *} \\
(1.160)\end{array}$ & $\begin{array}{l}1.506^{*} \\
(0.822)\end{array}$ & $\begin{array}{l}2.609^{* * *} \\
(0.860)\end{array}$ & $\begin{array}{l}1.936^{* *} \\
(0.888)\end{array}$ & $\begin{array}{l}1.919^{* *} \\
(0.802)\end{array}$ & $\begin{array}{l}1.739^{* *} \\
(0.748)\end{array}$ & $\begin{array}{l}2.434^{* * *} \\
(0.881)\end{array}$ \\
\hline $\begin{array}{l}\text { Firma } \\
\text { Büyüklüğü }\end{array}$ & $\begin{array}{l}0.372^{* * *} \\
(0.096)\end{array}$ & $\begin{array}{l}0.389 * * * \\
(0.082)\end{array}$ & $\begin{array}{l}0.398^{* * *} \\
(0.084)\end{array}$ & $\begin{array}{l}0.400^{* * *} \\
(0.080)\end{array}$ & $\begin{array}{l}0.345^{* * *} \\
(0.075)\end{array}$ & $\begin{array}{l}0.338^{* * *} \\
(0.082)\end{array}$ & $\begin{array}{l}0.314^{* * *} \\
(0.080)\end{array}$ \\
\hline $\begin{array}{l}\text { Borç Dışı } \\
\text { Vergi } \\
\text { Kalkanı }\end{array}$ & $\begin{array}{l}-0.957 \\
(10.114)\end{array}$ & $\begin{array}{l}9.739 \\
(9.570)\end{array}$ & $\begin{array}{l}3.373 \\
(8.564)\end{array}$ & $\begin{array}{l}1.201 \\
(5.785)\end{array}$ & $\begin{array}{l}-4.879 \\
(6.862)\end{array}$ & $\begin{array}{l}-3.604 \\
(7.368)\end{array}$ & $\begin{array}{l}-20.835^{*} \\
(10.383)\end{array}$ \\
\hline $\begin{array}{l}\text { Piyasa } \\
\text { Değeri } \\
\text { Defter } \\
\text { Değeri }\end{array}$ & $\begin{array}{l}-0.447^{*} \\
(0.234)\end{array}$ & $\begin{array}{l}-0.449^{* *} \\
(0.184)\end{array}$ & $\begin{array}{l}-0.526^{* *} \\
(0.249)\end{array}$ & $\begin{array}{l}-0.454^{* *} \\
(0.208)\end{array}$ & $\begin{array}{c}-0.288^{*} \\
(0.157)\end{array}$ & $\begin{array}{c}-0.329 * \\
(0.197)\end{array}$ & $\begin{array}{l}-0.103 \\
(0.133)\end{array}$ \\
\hline $\begin{array}{l}\text { Sektör } \\
\text { Kaldıraç } \\
\text { Ortalaması }\end{array}$ & $\begin{array}{l}-1.539 \\
(2.389)\end{array}$ & $\begin{array}{l}0.473 \\
(1.476)\end{array}$ & $\begin{array}{l}6.891^{* *} \\
(3.027)\end{array}$ & $\begin{array}{l}6.674^{* *} \\
(3.141)\end{array}$ & $\begin{array}{l}7.012^{* *} \\
(3.354)\end{array}$ & $\begin{array}{l}4.807^{* *} \\
(2.279)\end{array}$ & $\begin{array}{l}2.426 \\
(1.639)\end{array}$ \\
\hline $\begin{array}{l}\text { Sabit } \\
\text { Terim }\end{array}$ & $\begin{array}{l}-5.580^{* * *} \\
(1.687)\end{array}$ & $\begin{array}{l}5.713^{* * *} \\
(1.280)\end{array}$ & $\begin{array}{l}-6.863^{* * *} \\
(1.473)\end{array}$ & $\begin{array}{l}-6.639 * * * \\
(1.506)\end{array}$ & $\begin{array}{l}-5.976^{* * *} \\
(1.351)\end{array}$ & $\begin{array}{l}5.495^{* * *} \\
(1.406)\end{array}$ & $\begin{array}{l}-4.790^{* * *} \\
(1.310)\end{array}$ \\
\hline $\begin{array}{l}\text { RESET2 } \\
\text { (p-değeri) }\end{array}$ & 0.0346 & 0.1315 & 0.307 & 0.1944 & 0.3448 & 0.2434 & 0.2225 \\
\hline $\begin{array}{l}\text { RESET3 } \\
\text { (p-değeri) }\end{array}$ & 0.105 & 0.3083 & 0.308 & 0.4227 & 0.6122 & 0.434 & 0.447 \\
\hline $\begin{array}{l}\text { GOFF1 } \\
\text { (p-değeri) }\end{array}$ & 0.036 & 0.1717 & 0.4301 & 0.2181 & 0.3992 & 0.2206 & 0.2573 \\
\hline $\begin{array}{l}\text { GOFF2 } \\
\text { (p-değeri) }\end{array}$ & 0.031 & 0.1768 & 0.2131 & 0.1649 & 0.2933 & 0.2603 & 0.2267 \\
\hline $\begin{array}{l}\text { GGOF } \\
\text { (p-değeri) }\end{array}$ & 0.097 & 0.3891 & 0.162 & 0.3378 & 0.4345 & 0.4585 & 0.4728 \\
\hline $\mathrm{N}$ & 214 & 240 & 247 & 255 & 258 & 258 & 255 \\
\hline Pseudo R2 & 0.190 & 0.21 & 0.22 & 0.22 & 0.17 & 0.17 & 0.16 \\
\hline
\end{tabular}

Tablo 3a ve Tablo 3b'de 2-aşamalı kesirli regresyon modelinin her iki aşaması için katsayı tahminleri, katsayıların standart hataları ve p-değerleri verilmiștir. Ayrıca, fonksiyonel form spesifikasyonunun doğruluğunu test etmek için kullanılan Ramsey RESET ve GOFF testlerine ait p-değerleri de tabloda yer almıştır. Bu testler, 1. aşamada lojistik, 2. aşamada ise normal bağlantı fonksiyonlarının geçerliliğini test etmektedir.
$\mathrm{Bu}$ testlerin tümü için sıfır hipotezi model spesifikasyonunun doğru olduğu şeklindedir (Ramalho vd., 2014). Tabloda görüldüğü gibi hemen tüm yıllara ait yatay kesit modelleri için sıfır hipotezi reddedilememiștir. Dolayısı ile elde edilen sonuçlar yorumlanabilir.

Yatay kesit analiz sonucunda, hemen tüm yıllar için, varlık yapısı ve firma büyüklüğü değişkenleri ile kaldıraçsız bir firmanın ilk defa finansal borç kullanma olasılığı arasında pozitif 
bir ilişki olduğu görülmüştür. Diğer taraftan, piyasa değeri-defter değeri oranı arttıkça kaldıraçsız bir firmanın finansal borç kullanmaya başlama olasılığı azalmaktadır. Tüm yıllar için olmasa da karlılık değiş̧keninin katsayısı da negatif ve anlamlı bulunmuştur. Son olarak kaldıraçsız firmaların borç kullanmaya başlama kararlarında faaliyet gösterdikleri sektörün ortalama kaldıraç oranının da etkili olduğu görülmüștür.
Sadece kaldıraçlı firmaların dâhil edildiği analizin ikinci aşamasındaki sonuçlara bakıldığında ise, varlık yapısı ve firma büyüklüğü değişkenlerine ait katsayılarının anlamlılıkları büyük ölçüde değişmezken piyasa değeri defter değeri değișkeninin anlamlılığının kaybolduğu görülmektedir. Buna karşın sektör kaldıraç oranı ve karlılık değişkenlerinin anlamlılıkları artmıştır.

Tablo 3b: İki-aşamalı yatay kesit kesirli regresyon modeli kesirli regresyon bileşeni

$\mathrm{Bu}$ tabloda yatay kesit veri ile tahmin edilen 2-aşamalı kesirli regresyon modelinin sonuçları verilmiştir. Bağımlı değiş̧ken olarak Kaldıraç 2 oranı kullanılmıştır. Varyans-kovaryans matrisinin hesaplanmasında robust tahmin ediciler kullanılmıștır. Robust standart hatalar parantez içinde verilmiştir. “*”, “**” ve “***” sırasıyla\% 10,\% 5 ve\% 1 düzeyinde anlamlılığı göstermektedir. Değişken açılkamaları ise Ek 1'e verilmiștir.

\begin{tabular}{|c|c|c|c|c|c|c|c|}
\hline & 2011 & 2012 & 2013 & 2014 & 2015 & 2016 & 2017 \\
\hline Karlılık & $\begin{array}{l}-3.516^{* *} \\
(1.533)\end{array}$ & $\begin{array}{l}-1.989 \\
(1.252)\end{array}$ & $\begin{array}{l}-3.889 * * \\
(1.689)\end{array}$ & $\begin{array}{l}-3.999 * * * \\
(1.372)\end{array}$ & $\begin{array}{l}-0.146 \\
(0.349)\end{array}$ & $\begin{array}{l}-2.694^{* * *} \\
(0.872)\end{array}$ & $\begin{array}{l}-1.055 \\
(1.379)\end{array}$ \\
\hline $\begin{array}{l}\text { Varlık } \\
\text { Yapısı }\end{array}$ & $\begin{array}{l}0.341 \\
(0.647)\end{array}$ & $\begin{array}{l}0.904 \\
(0.629)\end{array}$ & $\begin{array}{l}1.074^{* *} \\
(0.478)\end{array}$ & $\begin{array}{l}1.817^{* * * *} \\
(0.446)\end{array}$ & $\begin{array}{l}1.746^{* * *} \\
(0.410)\end{array}$ & $\begin{array}{l}1.465^{* * *} \\
(0.384)\end{array}$ & $\begin{array}{l}1.365^{* * *} \\
(0.377)\end{array}$ \\
\hline $\begin{array}{l}\text { Firma } \\
\text { Büyüklüğü }\end{array}$ & $\begin{array}{l}0.150^{* * *} \\
(0.052)\end{array}$ & $\begin{array}{l}0.183^{* * *} \\
(0.047)\end{array}$ & $\begin{array}{l}0.085^{* *} \\
(0.042)\end{array}$ & $\begin{array}{l}0.102^{* * *} \\
(0.036)\end{array}$ & $\begin{array}{l}0.107^{* * *} \\
(0.035)\end{array}$ & $\begin{array}{l}0.107^{* *} \\
(0.043)\end{array}$ & $\begin{array}{l}0.081^{* *} \\
(0.038)\end{array}$ \\
\hline $\begin{array}{l}\text { Borç Dışı } \\
\text { Vergi } \\
\text { Kalkanı }\end{array}$ & $\begin{array}{l}3.755 \\
(6.370)\end{array}$ & $\begin{array}{l}1.243 \\
(5.866)\end{array}$ & $\begin{array}{l}1.102 \\
(5.187)\end{array}$ & $\begin{array}{l}-0.612 \\
(3.650)\end{array}$ & $\begin{array}{l}-5.547 \\
(3.720)\end{array}$ & $\begin{array}{l}2.397 \\
(5.145)\end{array}$ & $\begin{array}{l}4.980 \\
(5.004)\end{array}$ \\
\hline $\begin{array}{l}\text { Piyasa } \\
\text { Değeri } \\
\text { Defter } \\
\text { Değeri }\end{array}$ & $\begin{array}{l}0.099 \\
(0.114)\end{array}$ & $\begin{array}{l}0.260^{*} \\
(0.154)\end{array}$ & $\begin{array}{l}0.139 \\
(0.165)\end{array}$ & $\begin{array}{l}0.113 \\
(0.125)\end{array}$ & $\begin{array}{l}0.077 \\
(0.122)\end{array}$ & $\begin{array}{l}0.217 \\
(0.163)\end{array}$ & $\begin{array}{l}0.001^{*} \\
(0.050)\end{array}$ \\
\hline $\begin{array}{l}\text { Sektör } \\
\text { Kaldıraç } \\
\text { Ortalaması }\end{array}$ & $\begin{array}{l}4.141^{* * *} \\
(0.774)\end{array}$ & $\begin{array}{l}1.812^{* *} \\
(0.820)\end{array}$ & $\begin{array}{l}2.480^{*} \\
(1.272)\end{array}$ & $\begin{array}{l}2.178^{* *} \\
(1.108)\end{array}$ & $\begin{array}{l}1.946^{* *} \\
(0.896)\end{array}$ & $\begin{array}{l}2.184^{* * *} \\
(0.756)\end{array}$ & $\begin{array}{l}0.778 \\
(0.829)\end{array}$ \\
\hline $\begin{array}{l}\text { Sabit } \\
\text { Terim }\end{array}$ & $\begin{array}{l}-4.858^{* * *} \\
(0.942)\end{array}$ & $\begin{array}{l}-5.642^{* * *} \\
(0.964)\end{array}$ & $\begin{array}{l}-3.434^{* * *} \\
(0.784)\end{array}$ & $\begin{array}{l}-3.848^{* * *} \\
(0.669)\end{array}$ & $\begin{array}{l}-3.807^{* * *} \\
(0.658)\end{array}$ & $\begin{array}{l}-3.995^{* * *} \\
(0.818)\end{array}$ & $\begin{array}{l}-3.168^{* * *} \\
(0.694)\end{array}$ \\
\hline $\begin{array}{l}\text { RESET2 } \\
\text { (p-değeri) }\end{array}$ & 0.997 & 0.103 & 0.5157 & 0.1188 & 0.7641 & 0.986 & 0.2517 \\
\hline $\begin{array}{l}\text { RESET3 } \\
\text { (p-değeri) }\end{array}$ & 0.977 & 0.260 & 0.6534 & 0.2166 & 0.5418 & 0.3537 & 0.4887 \\
\hline $\begin{array}{l}\text { GOFF1 (p- } \\
\text { değeri) }\end{array}$ & 0.9905 & 0.1014 & 0.4976 & 0.1052 & 0.8272 & 0.8775 & 0.2443 \\
\hline $\begin{array}{l}\text { GOFF2 (p- } \\
\text { değeri) }\end{array}$ & 0.9937 & 0.1032 & 0.5247 & 0.1232 & 0.7298 & 0.9673 & 0.2692 \\
\hline $\begin{array}{l}\text { GGOF } \\
\text { (p-değeri) }\end{array}$ & 0.9829 & 0.2567 & 0.6265 & 0.2312 & 0.4904 & 0.3803 & 0.4916 \\
\hline $\mathrm{N}$ & 146 & 156 & 170 & 177 & 183 & 181 & 183 \\
\hline Pseudo R2 & 0.19 & 0.16 & 0.11 & 0.19 & 0.15 & 0.21 & 0.14 \\
\hline
\end{tabular}




\subsection{Panel veri analizi sonuçları}

Zaman serisi analizlerinin doğru sonuçlar vermesi için oldukça önem arz eden durağanlık hem zaman serisi hem de yatay kesit boyutlara sahip panel veri setleri için de oldukça önemlidir. Özellikle $\mathrm{T}>\mathrm{N}$ olduğunda serilerin durağanlığı mutlaka kontrol edilmelidir. $\mathrm{Bu}$ çalışmanın zaman serisi boyutu oldukça kısa olmasına rağmen yine de durağanlık analizi yapılmıştır.

Panel birim kök testleri birinci ve ikinci nesil olmak üzere iki gruba ayrılmaktadır. Birinci nesil testler yatay kesit bağımlılık probleminin olmadığını varsayarken, ikinci nesil testler bu problemin varlığını kabul eder ve durağanlığı test ederken yatay kesit bağımlılığı da dikkate alırlar. Yatay kesit bağımlılığın var olduğu durumlarda bu problemi dikkate almayan testler kullanıldığında yanıltıcı sonuçlar elde edilmektedir (Pesaran, 2004).

Bu çalışmada, yatay kesit bağımlılığı test etmek için Pesaran (2004) ve Pesaran (2015)'de açıklanan CD-test, Friedman (1937) ve Frees (1995; 2004) testleri yapılmıştır. Dengesiz paneller için ilk test dışındakilerin uygun olmaması sebebi ile yatay kesit testleri esnasında eksik verisi olan değişkenler model dışında bırakılmıştır. Tüm bu testlerden elde edilen sonuçlar veri setinde güçlü yatay kesit bağımlılığın olduğunu göstermektedir. Dolayısı ile durağanlığın test edilmesi için ikinci nesil panel birim kök testlerinden olan ve yatay kesit bağımlılığı dikkate alan Pesaran(2004) panel birim kök testi (CADF) ve Pesaran (2007) panel birim kök testi (CIPS) kullanılmak istenmiștir. Ancak zaman boyutu sadece yedi yll olduğu için geçerli sonuçlar elde edilememiștir. $\mathrm{Bu}$ nedenle seriler düzeylerinde modele dâhil edilmiştir. Ayrıca sonuçların güvenilirliğini test etmek amacı ile serilerin birinci farkları ile de analizler tekrar edildiğinde katsayıların işaret ve anlamlılıkları değişmemiştir. Bu nedenle bir sonraki bölümde değişkenlerin düzeyleri ile yapılan analiz sonuçları verilmiştir.

Tablo 4: Yıllara göre borç kullanmayan firma sayıları

\begin{tabular}{llllllll}
\hline & 2011 & 2012 & 2013 & 2014 & 2015 & 2016 & 2017 \\
\hline \hline Kaldıraçsız Firma & 87 & 89 & 83 & 81 & 76 & 79 & 74 \\
Kaldıraçlı Firma & 174 & 172 & 178 & 180 & 185 & 182 & 187 \\
Toplam & 261 & 261 & 261 & 261 & 261 & 261 & 261 \\
Kaldıraçsız Firma Oranı & $\% 33$ & $\% 34$ & $\% 32$ & $\% 31$ & $\% 29$ & $\% 30$ & $\% 28$ \\
\hline
\end{tabular}

İlk aşamada, sıfır kaldıraç olgusunun Borsa İstanbul'daki geçerli olup olmadığ araştırılmıştır. Örneklem periyodundaki her bir yıl için çalışma kapsamındaki firmaların borç kullanma oranları Tablo 4'de verilmiştir. Ortalama olarak 261 firmanın \%31'inin borç kullanmadığını göstermektedir. Bu oran yıllar içerisinde süreklilik göstermektedir. Kaldıraçsız firmaların büyük kısmı araştırma periyodu olan yedi yıl boyunca hiç borç kullanmamış, bir kısmı ise ilk yıllarda borçlu firmalar iken sonradan kaldıraçsız olmuş ya da başlangıçta borç kullanmazken daha sonra borç kullanmaya başlamış firmalardır. Diğer bir ifade ile firmaların borç alma davranıșı süreklilik göstermektedir. Bu durum, Strabulaev ve Yang (2013) tarafindan ortaya atılan sıfır kaldıraç olgusunun BİST'de geçerli olduğu sonucunu ortaya koymuștur. Ramalho ve Silva (2009) özellikle küçük ve halka açık olmayan firmalar arasında bu oranın çok daha yüksek olduğunu bulgulamışlardır. Strabulaev ve Yang (2013) ise Compustat veri tabanında yer alan ABD firmaları üzerinde yaptıkları incelemede 2003 yılı itibari ile bu oranın \%23.7 olduğunu hesaplamışlardır.

Panel veri setinde panel etkinin var olup olmadığını test etmek amacı ile Breusch-Pagan LM testi yapılmıștır. Testin Ki-Kare istatistiği 
(p-değeri) 1619.62(0.000) olarak hesaplandı̆̆ için panel veri tahmin metotlarının kullanılmasına karar verilmiștir. Daha sonra ise rassal etkiler varsayımının mı yoksa sabit etkiler varsayımının mı kullanılması gerektiğine karar vermek için Hausman testi kullanılmıştır. Ki-kare test istatistiği(p-değeri) 2.98(0.9557) olarak bulunduğu için bireysel etkilerin rassal olduğu varsayımı reddedilememiştir. Dolayısı ile analiz rassal etkiler varsayımı altında yapılmıștır.

Analizin birinci aşamasında eşitlik (1)'de verilen panel ikili tepki modeli tahmin edilmiştir. Sonuçlar Tablo 5'de verilmiştir. Bu lojistik modelde, bağımlı değişken olarak bilançolarında uzun vadeli borç değerleri rapor edilmemiş firmalar için 0 , diğer firmalar için ise 1 değerini alan bir kukla değişken kullanılmıştır.

Daha önceki literatür ile uyumlu bir şekilde, kaldıraçsız bir firmanın borç kullanmaya başlama olasılığı ile karlılığı arasında negatif bir ilișkili olduğu sonucuna ulaşılmıștır (Strabulaev, 2007; Kieschnick ve Moussavi, 2018).

Finansman hiyerarşisi teorisine göre firmalar yatırımlarını içsel finansmanla finanse etmeyi borç ya da yeni hisse senedi ihracı ile finansmana tercih edecekleri için, karlı firmaların borç kullanmaya başlama olasılı̆̆ı daha düşüktür.

Varlık yapısı, firma büyüklüğü, piyasa değeridefter değeri oranı ve sektör ortalaması değişkenlerinin de istatistiki olarak anlamlı katsayılara sahip olduğu görülmüștür. Tablo 5 'deki sonuçlara göre firmalar sabit varlıklarını arttırdıkça ve büyüdükçe borç kullanmaya başlama olasılıkları artmaktadır. Yine literatür ile uyumlu şekilde firmaların piyasa değeri defter değeri oranı arttıkça borç kullanma ihtimali azalmaktadır. Bazı sektörlerde diğerlerine nazaran daha yüksek kaldıraçlı firmaların faaliyet gösterdiği bilinmektedir. $\mathrm{Bu}$ sektörlerdeki firmaların borç kullanmaya başlama olasıllı̆ı diğer sektörlerdeki firmalardan çok daha yüksektir.
Tablo 5: Panel ikili tepki modeli

Bu tabloda panel veri ile tahmin edilen 2-aşamalı kesirli regresyon modelinin birinci aşama sonuçları verilmiştir. Varyans-kovaryans matrisinin hesaplanmasında robust tahmin ediciler kullanılmıştır. Robust standart hatalar parantez içinde verilmiştir. “*”, “**” ve “***” sırasıyla\% 10,\% 5 ve\% 1 düzeyinde anlamlılı̆ğ göstermektedir. Değissken açılklamaları ise Ek 1'e verilmiştir.

\begin{tabular}{ll}
\multicolumn{1}{c}{ Bağımlı Değişken } & $\begin{array}{l}\text { Kaldıraç Kukla } \\
\text { Değişkeni }\end{array}$ \\
\hline \hline Karlılık & $-3.540^{* * *}(1.180)$ \\
Varlı Yapısı & $4.817^{* * *}(1.193)$ \\
Firma Büyüklüğu & $0.685^{* * *}(0.129)$ \\
Borç Dışı Vergi Kalkanı & $4.175(9.586)$ \\
Piyasa Değeri Defter & $-0.569^{* * *}(0.167)$ \\
Değeri & \\
Sektör Kaldıraç & $14.097^{* * *}(4.690)$ \\
Ortalaması & $0.068(0.075)$ \\
Enflasyon & $8.441(5.389)$ \\
GSYì Büyümesi & $-12.609^{* * *}(2.438)$ \\
Sabit Terim & Var \\
\hline Yıl Etkisi & 1727 \\
Gözlem Sayısı & 261 \\
Firma Sayısı & $2011-2017$ \\
Zaman Periyodu & 100.670 \\
Ki-Kare & 0.000 \\
P değeri & \\
\hline
\end{tabular}

Analizin ikinci aşamasında ise kaldıraçlı firmaların kullandıkları borç oranını etkileyen faktörler analiz edilmek istenmiştir. Bunun için sadece kaldıraçlı firmalardan oluşan bir altörneklem oluşturulmuştur. İlk aşamada bağımlı değişkenler olan Kaldıraç 1 ve Kaldıraç 2 değişkenlerinin dağılımları incelenmiştir. Bu değişkenler 0 ve 1 aralığında ( 0 ve 1 haricinde) kesirli değer almaktadırlar.

2 aşamalı kesirli regresyon modeli yaklaşımının ikinci aşaması için eşitlik(2)'de verilen kesirli regresyon modeli Papke ve Wooldridge (2008) spesifikasyonları ile tahmin edilmiştir. Sonuçlar Tablo 6'de verilmiştir. Bu model tahmin edilirken sadece kaldıraç kullanan firmalara ait veriler kullanılmıştır. Bağımlı değişken olarak Kaldıraç 1 ve 2 değişkenleri ile model tahmini yapılmıștır. Kesirli regresyon modeli kullanılmasının sonuçlar üzerinde belirgin bir fark oluşturup 
oluşturmadığını anlamak amacı ile EKK rassal etkiler modeli tahmin sonuçlarına da yer verilmiştir.

Kesirli regresyon modelinden elde edilen sonuçlar rassal etkiler modelinden elde edilenlerle birkaç noktada farklılaşmaktadır. Rassal etkiler modeline göre her iki bağımlı değişken ile kurulan modelde de $\% 5$ düzeyinde anlamlılığa sahip olan karlılık değişkeni kesirli regresyon modeli ile yapılan tahminlerde anlamlılığını yitirmiștir. Diğer taraftan rassal etkiler modelinde \%10 düzeyinde olan firma büyüklüğü değişkeninin anlamlılığı \%5'e yükselmiştir. Son olarak, kaldıraç 2 değişkeni ile kurulan rassal etkiler modelinde \%10 anlamlılık düzeyine sahip olan enflasyon değişkeni kesirli regresyon modelinde etkisini tamamen kaybetmiştir.

Tablo 6: Kesitli regresyon modeli

$\mathrm{Bu}$ tabloda panel veri ile tahmin edilen rassal etkiler modeli ve 2-aşamalı kesirli regresyon modelinin ikinci aşama sonuçları verilmiştir. 2-aşamalı modelin varyans-kovaryans matrisinin hesaplanmasında firma düzeyinde kümülemeye imkân sağlayan sandwich tahmin ediciler kullanılmıştır. Robust standart hatalar parantez içinde verilmiştir. “*”, “**” ve “***” sırasıyla\% 10,\% 5 ve\% 1 düzeyinde anlamlılı̆̆ göstermektedir. Değişken açılamaları ise Ek 1'e verilmiştir.

\begin{tabular}{lllll}
\hline \multirow{2}{*}{$\begin{array}{l}\text { Model } \\
\text { Bağımlı Değişken }\end{array}$} & Kaldıraç 1 & Kaldıraç 2 & \multicolumn{2}{l}{ Kesirli Regresyon Modeli } \\
\hline \multirow{2}{*}{ Karlılık } & $-0.078^{* *}$ & $-0.084^{* *}$ & -0.763 & Kaldıraç 2 \\
& $(0.033)$ & $(0.037)$ & $(0.524)$ & $\left(0.574^{*}\right.$ \\
\multirow{2}{*}{ Varlık Yapısı) } & $0.282^{* * *}$ & $0.204^{* * *}$ & $1.791^{* * *}$ & $1.371^{* * *}$ \\
& $(0.034)$ & $(0.039)$ & $(0.367)$ & $(0.360)$ \\
\hline \multirow{2}{*}{ Firma Büyüklüğü } & $0.007^{*}$ & $0.008^{*}$ & $0.082^{* * *}$ & $0.096^{* * *}$ \\
& $(0.004)$ & $(0.004)$ & $(0.032)$ & $(0.032)$ \\
\hline \multirow{2}{*}{ Borç Dışı Vergi Kalkanı } & $-0.549^{* *}$ & 0.136 & -5.065 & 0.242 \\
& $(0.276)$ & $(0.311)$ & $(3.181)$ & $(3.527)$ \\
\multirow{2}{*}{ Piyasa Değeri Defter Değeri } & $-0.045^{* * *}$ & 0.000 & $-0.759^{* * *}$ & 0.076 \\
& $(0.005)$ & $(0.006)$ & $(0.121)$ & $(0.082)$ \\
\hline \multirow{2}{*}{ Sektör Kaldıraç Ortalaması } & $0.551^{* * *}$ & $0.223^{* * *}$ & $2.596^{* * *}$ & $2.096^{* * *}$ \\
& $(0.117)$ & $(0.061)$ & $(0.813)$ & $(0.619)$ \\
\hline \multirow{2}{*}{ Enflasyon } & 0.003 & $0.005^{*}$ & 0.0230 & -0.001 \\
& $(0.002)$ & $(0.003)$ & $(0.017)$ & $(0.022)$ \\
\hline \multirow{2}{*}{ GSYï Büyümesi } & $-0.618^{* * *}$ & $-0.928^{* * *}$ & $-3.941^{* * *}$ & $-4.919^{* * *}$ \\
& $(0.162)$ & $(0.160)$ & $(1.236)$ & $(1.067)$ \\
\hline \multirow{2}{*}{ Sabit } & -0.012 & -0.014 & $-2.729^{* * *}$ & $-3.501^{* * *}$ \\
& $(0.068)$ & $(0.076)$ & $(0.587)$ & $(0.578)$ \\
\hline Yıl Etkisi & Var & Var & Var & Var \\
\hline Gözlem Sayısı & 1196 & 1196 & 1196 & 1196 \\
Firma Sayısı & 172 & 172 & 172 & 172 \\
\hline
\end{tabular}

Kesirli regresyon modeli sonuçlarına bakıldığında ilk dikkat çeken husus, karlılığın piyasa değeri ile hesaplanan kaldıraç oranının üzerinde etkisiz olmasıdır. Defter değeri ile hesaplanan kaldıraç oranı üzerinde ise oldukça zayıf bir etkiden söz edilebilir. $\mathrm{Bu}$ durum finansman hiyerarşisi teorisinin beklentisini doğrulamamaktadır. Ancak, analizin birinci aşamasında bulgulanan karlılık ve ilk defa borç kullanma kararı arasındaki negatif ilişki bu teoriyi desteklemektedir. Karlı firmalar borç ile finansmanı tercih etmemektedir. Sonuç olarak, finansman hiyerarşisi teorisi kaldıraçsız firmaların ilk defa borç kullanma kararlarında karlılığın etkisini açıklayabilir.

Varlık yapısı ve firma büyüklüğü değişkenleri modelin birinci aşamasında olduğu gibi ikinci aşamasında da anlamlı bulunmuştur. Bu bulgu, 
dengeleme teorisini destekler niteliktedir. Firmaların hem ilk defa borç alma kararlarında, hem de borç kullanmaya başladıktan sonraki kaldıraç oranlarının belirlenmesinde varlık yapısı ve firma büyüklüğünün etkili olduğunu göstermektedir. Piyasa değeri defter değeri oranı ise sadece piyasa değeri ile hesaplanan kaldıraç oranını etkilemektedir. Ortalama kaldıraç oranı yüksek olan sektörlerde faaliyet gösteren firmaların hem kaldıraç kullanmaya hem de kaldıraç oranını yükseltmeye yatkın oldukları da bulgular arasındadır. Son olarak GSYİH büyüme oranı arttığında kaldıraç oranının azaldığı sonucuna ulaşılmıştır.

\section{SONUÇ}

$\mathrm{Bu}$ çalışmanın amacı, son yıllarda uluslararası ampirik sermaye yapısı literatürde tartışılan ancak Türkiye verisi kullanılarak yapılmış sermaye yapısı çalışmalarında henüz yer bulamamış birkaç yeni hususu dikkate alarak Türkiye'deki sermaye yapısı literatürüne katkı sağlamaktır.

$\mathrm{Bu}$ hususların ilki kaldıraç oranının hesaplanması ile ilgilidir. Kaldıraç oranının, finansal borcun toplam dişsal finansman içindeki oranını göstermesi gerekmektedir. Ancak literatürde sıklıkla kullanılan finansal borcun toplam varlıklara bölünmesi ile hesap edilen kaldıraç oranının paydasında dıșsal finansmanın yanı sıra faiz ödenmeyen kısa vadeli yükümlülükler de yer almaktadır. Dolayısı ile bu oran kullanıldığında, finansal borçluluğu düşük olan firmaların yanı sıra borç dışı yükümlülükleri fazla olan firmalar için de kaldıraç oranı düşük çıkacaktır. Sonuç olarak, doğru kaldıraç oranı finansal borcun toplam yatırıma oranı şeklinde hesaplanmalıdır.

İkinci husus ise sıfır kaldıraç olgusudur. Strabulaev (2007) tarafindan ortaya konan bu olgu, azımsanamayacak sayıda firmanın kaldıraç kullanmamayı tercih ettiği gerçeğine dikkat çeker. Bu tercih, modern sermaye yapısı teorileri ile açıklanamaz. Bu olgunun doğal bir sonucu kaldıraçsız bir firmanın borç kullanmaya başlama kararını etkileyen faktörler ile kaldıraçlı bir firmanın kullandığı borç oranını etkileyen faktörlerin birbirinden farklı olabileceğidir. Son birkaç yılda yapılan çalışmalar sıfır kaldıraç olgusunun pek çok ülkede geçerli olduğunu kanıtlamıştır ( Bessler vd., 2013; Ramalho ve Silva 2009); Dang, 2013; El Ghoul vd., 2017). Ancak Borsa İstanbul'da sıfır kaldıraç olgusu daha önce araştırılmamıştır.

$\mathrm{Bu}$ çalışmada dikkate alınan son husus ise kaldıraç oranının kesirli bir değişken olmasıdır. 0 ile 1 aralığında değer alan kaldıraç oranının koşullu beklentisi doğrusal bir fonksiyon olamaz. Bu nedenle, lineer bir model yerine kesirli regresyon modeli kullanılması daha doğru olacaktır.

$\mathrm{Bu}$ hususların hepsini dikkate alan bu çalışmada, Borsa İstanbul'da işlem gören ve finans dışı sektörlerde faaliyet gösteren 261 halka açık firmanın sermaye yapısı belirleyicileri Ramalho vd. (2011) tarafından geliştirilen 2-aşamalı Kesirli Regresyon Modeli (Two-Part Fractional Regression Model) yaklaşımı kullanılarak araştırılmıştır.

$\mathrm{Bu}$ çalışmanın bulguları iki maddede özetlenebilir:

- $\quad$ Bazı firmalar sermaye yapısı teorilerinin aksine kaldıraç kullanmazlar. Çalıșma kapsamındaki 261 firmanın \%31'inin kaldıraç kullanmadığı tespit edilmiştir. Bu oran yıllar içerisinde süreklilik göstermektedir. Diğer bir ifade ile sıfır kaldıraç olgusunun Borsa İstanbul'da geçerli olduğu görülmüştür. Dolayısı ile sermaye yapısı belirleyicilerini araştıran ampirik çalışmalarda kaldıraçsız ve kaldıraçlı firmaların verilerini ayrı ayrı analiz eden iki aşamalı bir yaklaşım kullanılması daha doğru sonuç verecektir.

- Kaldıraçsız bir firmanın ilk defa borç alma kararını etkileyen faktörler ile kaldıraçlı bir firmanın kaldıraç oranını etkileyen faktörler tamamen aynı değildir. Varlık yapısı, firma büyüklüğü ve sektör kaldıraç ortalaması her iki durumda da etkili belirleyicilerdir. Ancak karlılık ve piyasa değeri defter değeri oranı kaldıraçsız bir firmanın kaldıraç kullanmaya başlamasında önemli iken kaldıraçlı bir firmanın kaldıraç oranı üzerinde etkili değildir. 


\section{REFERANSLAR}

ANTONIOU, A., GUNEY, Y., Paudyal, K., (2008), "The Determinants of Capital Structure: Capital Market-oriented versus Bank-oriented Institutions", Journal of Financial and Quantitative Analysis, 43(01), 59-92.

ARELLANO, M., Bond, S., (1991), "Some Tests of Specification for Panel Data: Monte Carlo Evidence and an Application to Employment Equations", The Review of Economic Studies, 58(2), 277-297.

AYDIN, A. D., ÇAVDAR, Ş. Ç.., (2018), "Firma Optimal Sermaye Yapısının Belirlenmesi: Borsa İstanbul (BIST) 100 Endeksi Finans Dişı Firmalar Üzerinde Ampirik Bir Çalıșma", Atatürk Üniversitesi İktisadi ve İdari Bilimler Dergisi, 32(3), 845-857.

BALTAGİ, B., (2008), Econometric Analysis of Panel Data, West Sussex: John Wiley \& Sons.

BAUM, C., CAGLAYAN, M., RASHID, A., (2017), "Capital Structure Adjustments: Do macroeconomic and business risks matter?", Empirical Economics, 53(4), 1463-1502.

BESSLER, W., DROBETZ, W., HALLER, R., MEIER, I., (2013), "The International Zeroleverage Phenomenon", Journal of Corporate Finance, 23, 196-221.

BLUNDELL, R., BOND, S., (1998), "Initial Conditions and Moment Restrictions in Dynamic Panel Data Models", Journal of Econometrics, 87(1), 115-143.

BİLGİN, R., (2018), "Gelişmekte Olan Ülkelerde Sermaye Yapısı Belirleyicileri; Hiyerarşik Lineer Model Yaklaşımı", Hacettepe Üniversitesi İktisadi ve İdari Bilimler Fakültesi Dergisi, 36(3), 1-27.

BURUCU, H., ÖNDEŞ, T., (2016), “Türk İmalat Sanayi Firmalarının Sermaye Yapısını Etkileyen Faktörlerin Analizi", Çankırı Karatekin Üniversitesi İIBB Dergisi, 6(1), 201-225.

DANG, V. A., (2013), "An Empirical Analysis of Zero-leverage Firms: New Evidence from the
UK", International Review of Financial Analysis, 30, 189-202.

DE JONG, A., KABİR R., NGUYEN T. T., (2008). "Capital Structure Around the World: The Roles of Firm-and Country-specific Determinants", Journal of Banking and Finance, 32(9), 19541969.

DEMIRHAN, D. (2009). "Sermaye Yapısını Etkileyen Firmaya Özgü Faktörlerin Analizi: IMKB Hizmet Firmaları Üzerine Bir Uygulama", Ege Akademik Bakış Dergisi, 9(2), 677-697.

EL GHOUL, S., GUEDHAMI, O., KWOK, C., ZHENG, X.(2017). "Zero-leverage Puzzle: An International Comparison", Review of Finance, 22(3), 1063-1120.

FAN, J. P.H., TITTMAN, S., TWITE, G. (2012). “An International Comparison of Capital Structure and Debt Maturity Choices", Journal of Financial and Quantitative Analysis, 47(01), 23-56.

FREES, E. (1995). "Assessing Cross-sectional Correlation in Panel Data", Journal of Econometrics, 69(2), 393-414.

FREES, E. (2004). Longitudinal and Panel Data: Analysis and Applications in the Social Sciences, Cambridge University Press.

FRIEDMAN, M. (1937). "The Use of Ranks to Avoid the Assumption of Normality Implicit in the Analysis of variance", Journal of the American Statistical Association, 32(200), 675701.

FRANK, M., Goyal, V., (2009). "Capital Structure Decisions: Which Factors are Reliably Important?" Financial Management, 38(1), 137.

GONZÁLEZ, V., GONZÁLEZ, F. (2008). "Influence of Bank Concentration and Institutions on Capital Structure: New International Evidence", Journal of Corporate Finance, 14(4), 363-375.

GRAHAM, J., LEARY, M. (2011). "A Review of Empirical Capital Structure Research and Directions for the Future", Annual Review of 
Financial Economics, 3(1), 309-345. https://doi.org/10.1146/annurev-financial102710-144821

HARRIS, M., RAVIV, A. (1991),"The Theory of Capital Structure", The Journal of Finance, 46(1), 297-355.

HUANG, R., RITTER, J. (2009). “Testing Theories of Capital Structure and Estimating the Speed of Adjustment", Journal of Financial and Quantitative Analysis, 44(2), 237-271.

JENSEN, M. (1986). “Agency Costs of Free Cash Flow, Corporate Finance, and Takeovers", The American Economic Review, 76(2), 323-329.

KAYO, E., KIMURA, H. (2011). "Hierarchical Determinants of Capital Structure", Journal of Banking and Finance, 35(2), 358-371.

KIESCHNICK, R., MOUSSAWİ, R. (2018), "Firm Age, Corporate Governance, and Capital Structure Choices", Journal of Corporate Finance, 48, 597-614.

KISAKÜREK, M., AYDIN, Y. (2013), "İşletmelerde Sermaye Yapısı ile Kârlılık Arasındaki İlişkinin Analizi: 1992-2011 Yılları Arası Finansal Krizler Odaklı BiST'te bir Uygulama", Cumhuriyet Üniversitesi İktisadi ve İdari Bilimler Dergisi, 14(2), 97-121.

KÖKSAL, B., ORMAN, C. (2015), "Determinants of Capital Structure: Evidence from a Major Developing Economy", Small Business Economics, 44(2), 255-282.

MODİGLIANI, F., Miller, M. (1958), "The Cost of Capital, Corporation Finance and the Theory of Investment", The American Economic Review, 48(3), 261-297.

MODÍGLIANİ, F., MILLER, M. (1963), “Corporate Income Taxes and the Cost of Capital: a Correction", The American Economic Review, 53(3), 433-443.

MYERS, S., MAJLUF, N. (1984), “Corporate Financing and Investment Decisions When Firms Have Information That Investors Do Not Have", Journal of Financial Economics, 13(2), 187-221.
OZKAN, A. (2001), "Determinants of Capital Structure and Adjustment to Long Run Target: Evidence from UK Company Panel Data", Journal of Business Finance \& Accounting, 28(1-2), 175-198.

PAPKE, L., WOOLDRIDGE, J. (1996), "Econometric Methods for Fractional Response Variables with an Application to 401 (k) Plan Participation Rates", Journal of Applied Econometrics, 11(6), 619-632.

PAPKE, L., WOOLDRIDGE, J. (2008), “Panel Data Methods for Fractional Response Variables with an Application to Test Pass Rates", Journal of Econometrics, 145(1-2), 121133.

PARSONS, C., TİTMAN, S. (2007), "Empirical Capital Structure: A Review", Foundations and Trends in Finance, 3(1), 1-93.

PESARAN, H. (2004), "General Diagnostic Tests for Cross Section Dependence in Panels" https://www.econstor.eu/bitstream/10419/1 8868/1/cesifo1_wp1229.pdf (02.03.2019)

PESARAN, H. (2007), “A Simple Panel Unit Root Test in the Presence of Cross-section Dependence", Journal of Applied Econometrics, 22(2), 265-312.

PESARAN, H. (2015), “Testing Weak Crosssectional Dependence in Large Panels", Econometric Reviews, 34(6-10), 1089-1117.

RAJAN, R., ZINGALES, L. (1995), "What Do We Know About capital Structure? Some Evidence from International Data", The Journal of Finance, 50(5), 1421-1460.

RAMALHO, J., DA SİLVA, J. V.(2009), “A Twopart Fractional Regression Model for the Financial Leverage Decisions of Micro, Small, Medium and Large Firms", Quantitative Finance, 9(5), 621-636.

RAMALHO, E., RAMALHO, J., Murteira, J. (2014), "A Generalized Goodness-of-functional Form Test for Binary and Fractional Regression Models", The Manchester School, 82(4), 488507. 


\section{R. BILGIN}

RAMALHO, E., RAMALHO, J., MURTEİRA, J. (2011), "Alternative Estimating and Testing Empirical Strategies for Fractional Regression Models", Journal of Economic Surveys, 25(1), 19-68.

RAMALHO, J., RITA, R., Da SÍLVA, J. V. (2018), "The Impact of Family Ownership on Capital Structure of Firms: Exploring the Role of Zeroleverage, Size, Location and the Global Financial Crisis", International Small Business Journal, 36(5), 574-604.

STREBUlAEV, I. (2007), "Do Tests of Capital Structure Theory Mean What They Say?", The Journal of Finance, 62(4), 1747-1787.

STREBULAEV, I., Yang, B. (2013), "The Mystery of Zero-leverage Firms", Journal of Financial Economics, 109(1), 1-23.

TERIM, B., KAYALI, C. A. (2009), "Sermaye Yapısını Belirleyici Etmenler: Türkiye'de İmalat Sanayi Örneği", Celal Bayar Üniversitesi Sosyal Bilimler Dergisi, 7(1), 125-154.
TORAMAN, C., OKUYAN, A. (2009), "İşletmelerde Ortaklık Yapısında Yoğunlaşmanın Kaynak Yapısı Üzerindeki Etkisi: İMKB Şirketleri Üzerine bir Uygulama", Muhasebe ve Finansman Dergisi, (41), 72-81.

VENANZİ, D., NACCARATO, A., ABATE, G. (2014), "Does the Country Effect Matter in the Capital Structure Decisions of European Firms? EFMA 2014 Annual Meeting.

WOOLDRIDGE, J. (2011), Fractional response models with endogeneous explanatory variables and heterogeneity", In CHI11 Stata Conference. Stata Users Group. http://fmwww.bc.edu/repec/chic2011/chi11_ wooldridge.pdf (02.03.2019)

Welch, I. (2011), "Two Common Problems in Capital Structure Research: The Financial-debtto-asset ratio and Issuing Activity versus Leverage Changes", International Review of Finance, 11(1), 1-17. 